\title{
Penerapan Kaidah al-Ghunm bi al-Ghurm dalam Pembiayaan Mushārakah pada Perbankan Syariah
}

\author{
Hendri Hermawan Adinugraha \\ Universitas Dian Nuswantoro Semarang \\ email: hendri.hermawan@dsn.dinus.ac.id
}

\begin{abstract}
This purpose of this research is to describe the theoretical study of the principle of al-ghunm bi al-ghurm in detail and its implementation in mushärakah financing at Islamic banking. The type of research has been included in the library research category which is writing the data and information obtained from published sources. Therefore, this research was used literature research from journals, books and other sources related to the topic. This research used normative juridical approach, then in every analysis always refers main reference on primary sources, such as Umar Abdullah alKamil dissertation which entitled al-Qawa'id al-Fiqhiyyah al-Kubrā wa Atsaruhā fi al-Mu'āmalat al-Māliyah and paper by Walid Rashid Ibn As-Sa'idan about Qawā'id al-Buyu' wa Faräid al-Furu' to identify the concept of al-ghunm bi al-ghurm in mushārakah financing at Islamic banking.
\end{abstract}

Keywords: al-ghunm;al-ghurm; mushärakah .

\begin{abstract}
Abstrak: Tujuan penelitian ini adalah untuk mendeskripsikan dan menginterpretasikan hasil temuan/pengamatan mengenai konsep al-ghunm bi al-ghurm dalam pembiayaan mushärakah pada perbankan syariah. Jenis penelitian ini termasuk penelitian kepustakaan (library research) dimana pengumpulan data dan informasinya diperoleh dari sumber-sumber pustaka (bacaan) yang berasal dari buku, hasil penelitian, jurnal dan bahan-bahan bacaan lainnya yang masih ada relevansinya dengan topik ini. Penelitian ini menggunakan pendekatan yuridis normatif, maka dalam setiap analisa selalu merujuk (rujukan utama) pada sumber primer yaitu disertasi Umar Abdullah al-Kamil yang berjudul al-Qawa'íd al-Fiqhiyyah al-Kubrā wa Atharuhā fi alMu'āmalat al-Māliyah dan paper karya Walid Ibnu Rasyid As-Sa'idan tentang Qawā'id al-Buyu' wa Farāiḍ al-Furu' untuk mengidentifikasi konsep al-ghunm bi al-ghurm dalam pembiayaan mushārakah pada perbankan syariah.
\end{abstract}

Kata Kunci: al-ghunm; al-ghurm; mushārakah. 
Hendri Hermawan Adinugraha

\section{Pendahuluan}

Konsep dasar dalam perbankan syariah ialah konsep pembagian (sharing), baik keuntungan maupun kerugian (profit and loss sharing). Prinsip yang umum adalah siapa yang ingin mendapatkan hasil dari tabungannya, harus juga bersedia mengambil risiko. Bank syariah akan membagi juga kerugian perusahaan jika mereka menginginkan perolehan hasil dari modal mereka (Muhammad, Bank Syari'ah: Analisis Kekuatan, Peluang, Kelemahan dan Ancaman 2001). Hal ini selaras dengan kaidah fikih khusus di bidang muamalah atau transaksi yang berbunyi al-kharāj bi ald̦amān (hasil usaha muncul bersama biaya/hak mendapatkan hasil disebabkan oleh keharusan menanggung kerugian) (Mudjib 2001), dan senantiasa disambung dengan kaidah al-ghunm bi al-ghurm (profit muncul bersama risiko/risiko itu menyertai manfaat) (Djazuli 2006).

Idealnya, konsep inilah yang semestinya menjadi produk unggulan perbankan syariah. Karena dengan sistem bagi-hasil, perbankan syariah dalam mengambil profit-nya diharapkan tidak berpatokan pada pola suku bunga yang ditetapkan oleh pemerintah, akan tetapi mereka akan mampu mendapatkan hasil yang kompetitif ketika kinerja nasabah semakin baik. Namun demikian, pada realitannya pembiayaan muḍārabah dan mushārakah dengan konsep bagi hasil serta bagi rugi (profit and loss sharing) sampai saat ini merupakan pembiayaan yang jarang dipraktikkan atau diaplikasikan pada perbankan syariah. Justru sebaliknya, realita menunjukan bahwa pembiayaan murābaḥah ${ }^{1}$ malah menjadi produk

1 Walaupun akad pembiayaan murābaḥah termasuk dalam katagori jual beli, namun ini merupakan suatu hal baru dalam perbankan oleh karena istilah tersebut tidak dikenal dalam perbankan konvensional. Bai' al-murābahah adalah jual beli barang pada harga asal dengan tambahan keuntungan yang disepakati, penjual harus memberi tahu harga produk yang ia beli dan menentukan suatu keuntungan sebagai tambahannya (Antonio 2001) 
unggulan yang dominan diimplementasikan dalam pembiayaan pada perbankan syariah.

Penelitian yang dilakukan oleh Rejeki membuktikan bahwa jumlah nasabah bank syariah yang menggunakan skim murābaḥah senantiasa menunjukkan peningkatannya dari tahun ke tahun (Rejeki 2013). Mau tidak mau, input yang membangun ini harus diterima secara lapang dada oleh semua pihak guna kebaikan serta kemaslahatan perbankan syariah. Padahal konsep al-ghunm bi al-ghurm dalam perbankan syariah melalui produk pembiayaan mushārakah dengan konsep profit and loss sharing, seyogyanya dapat menjadi salah satu perbedaan mendasar antara perbankan syariah dengan perbankan konvensional. Sebab perbankan syariah selain memiliki tujuan komersil juga mempunyai sasaran untuk tercapainya kesejahteraan sosial dan kemaslahatan menyeluruh bagi masyarakat muslim maupun nonmuslim.

Sejak tahun 1998 sampai sekarang, pertumbuhan perbankan syariah di Indonesia semakin melaju dengan pesat. Hal ini terbukti dengan makin bermunculannya bank konvensional yang membuka cabang syariah. Signifikansi pertumbuhannya mencapai $40-45 \%$ per tahun, ini terlihat dari pertumbuhan aset, dana pihak ketiga, jaringan kantor, ekspansi pelayanan, peningkatan penghimpunan dana dan pembiayaan. Pembiayaan yang sering diaplikasikan pada perbankan syariah ialah pembiayaan dengan menggunakan prinsip jual beli (murābaḥah) karena lebih simpel dan lebih kecil risikonya. Akibatnya, sebagian kalangan mengklaim istilah "pembiayaan" pada perbankan syariah tidak jauh berbeda dengan istilah "kredit" pada perbankan konvensional. Padahal pembiayaan dengan prinsip bagi hasil (muḍārabah dan mushārakah ) seringkali dijadikan jargon pada sistem syariah tapi realitanya aplikasi pembiayaan ini jarang ditemukan di lapangan, dengan alasan implementasi prinsip bagi hasil dalam pembiayaan mushārakah pada perbankan syariah berpotensi menimbulkan risiko terlalu besar dan tidak mudah dalam operasionalnya. Oleh karena itu,

Economica: Jurnal Ekonomi Islam - Volume 8, Nomor 1 (2017) http://journal.walisongo.ac.id/index.php/economica 
Hendri Hermawan Adinugraha

implementasi kaidah al-ghunm bi al-ghurm dalam pembiayaan mushärakah pada perbankan syariah sangatlah relevan dan amat menarik untuk dibahas.

\section{Definisi al-ghunm bi al-Ghurm}

Kaidah al-ghunm bi al-ghurm dalam banyak literatur selalu bersandingan dengan kaidah al-kharāj bi al-ḍamān. Kaidah al-ghunm bi alghurm maknanya adalah profit muncul bersama risiko atau risiko itu menyertai manfaat. Maksud dari kaidah al-ghunm bi al-ghurm ialah bahwa seseorang yang memanfaatkan sesuatu harus menanggung risiko. Sedangkan menurut 'Umar Abdullah al-Kamil, makna yang tersirat dari kaidah ini adalah bahwa barang siapa yang memperoleh manfaat dari sesuatu yang dimanfaatkannya maka ia harus bertanggung jawab atas dharār atau ghurm serta damān yang akan terjadi (al-Kamil t.t).

Contohnya adalah pada pengenaan biaya notaris merupakan tanggung jawab pembeli kecuali ada kerelaan dari penjual untuk ditanggung bersama. Demikian pula halnya, seseorang yang meminjam barang, maka ia wajib mengembalikannya dan risiko biaya-biaya pengembaliannya.

\section{Turunan Kaidah al-ghunm bi al-Ghurm}

Di bawah ini terdapat beberapa derivasi kaidah al-ghunm bi al-ghurm yang dapat dirinci sebagai berikut, yaitu (Djazuli 2006):

\section{a. al-Kharāj bi al-ḍamān}

Dasar kaidah al kharāj bi al-ḍamān ialah hadis Nabi saw.:

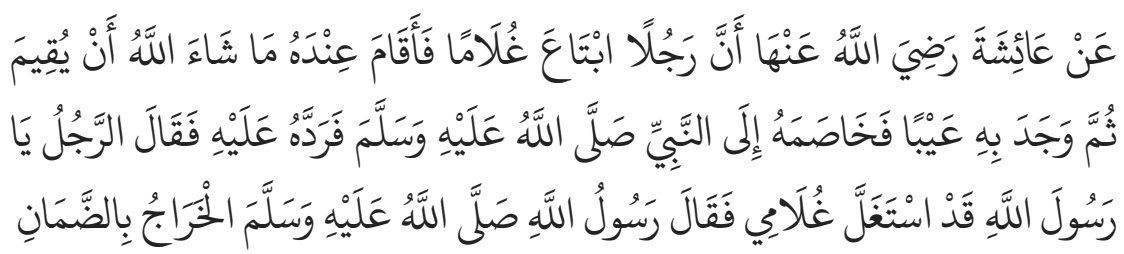

"Dari Aisyah bahwa seorang laki-laki membeli seorang budak kemudian budak tersebut tinggal bersamanya selama yang Allah kehendaki. Kemudian si pembeli mendapatkan cacat pada budak tersebut dan 
melaporkan kepada Nabi saw. Maka Nabi mengembalikan budak itu kepada laki-laki yang menjual. Lalu laki-laki itu berkata, "Wahai Rasulullah, ia (pembeli) telah mempekerjakan (mengambil manfaat) dari budakku". Rasulullah saw. bersabda, "Hak mendapatkan hasil itu disebabkan oleh keharusan menanggung kerugian". (HR. Abu Dawud)

Menurut perspektif Abu 'Ubaid, yang dimaksud dengan al-kharāj dalam hadis ini adalah pekerjaan hamba yang telah dibeli seseorang, yang kemudian orang tersebut menyuruh supaya hamba itu bekerja untuknya dalam waktu tertentu. Setelah itu diketahui adanya cacat yang disembunyikan oleh si penjual, kemudian ia kembalikan kepada penjual tersebut, dengan diambil seluruh uang harganya dan ia telah mendapatkan keuntungan mempekerjakan hamba itu, karena ia telah memberikan pembelanjaannya, dan apabila ada kerugian maka ia yang rugi (Ubaid t.t).

Jadi al-kharāj ialah segala apa yang keluar dari sesuatu, baik berupa pekerjaan, manfaat maupun benda-benda seperti buah dari pohon, susu dari kambing dan sebagainya, dan kesemuanya adalah menjadi milik dari yang menanggungnya, sebab kalau ada kerugian, maka ia pula yang menanggungnya.

Hadis ini adalah termasuk sebagian dari jawāmi' al-kalim, yakni kalimat yang ringkas tetapi artinya luas (Mudjib 2001). Sedangkan menurut A. Djazuli, arti asal al-kharāj adalah sesuatu yang dikeluarkan baik manfaat benda maupun pekerjaan, seperti pohon mengeluarkan buah atau binatang mengeluarkan susu (Djazuli 2006). Sedangkan al-ḍamān adalah ganti rugi. Etimologi ini juga tidak berbeda dengan etimologi yang dijelaskan oleh Umar Abdullah al-Kamil (al-Kamil t.t).

Contoh dalam kitab fikih klasik, seekor binatang dikembalikan oleh pembelinya dengan alasan cacat. Si penjual tidak boleh meminta bayaran atas penggunaan binatang tersebut. Karena penggunaan binatang itu sudah menjadi hak pembeli. Contoh lain yang relevan sekarang ini ialah garansi pada alat-alat elektronik.

Economica: Jurnal Ekonomi Islam - Volume 8, Nomor 1 (2017) http://journal.walisongo.ac.id/index.php/economica 
Hendri Hermawan Adinugraha

\section{b. al-Ajr wa al-ḍamān lā yajtami'ān}

Arti dari kaidah di atas adalah "pemberian upah dan tanggungjawab untuk mengganti kerugian tidak berjalan bersamaan". Yang disebut dengan dhāmān atau ganti rugi dengan kaidah tersebut adalah mengganti dengan barang yang sama. Apabila barang tersebut ada di pasaran atau membayar seharga barang tersebut apabila barangnya tidak ada di pasaran (Majallah alAhkam al-Adliyyah n.d.). Contoh, seseorang penyewa kendaraan penumpang untuk membawa keluarganya, tetapi si penyewa menggunakannya untuk membawa barang-barang yang berat yang mengakibatkan kendaraan tersebut rusak berat. Maka, si penyewa harus mengganti kerusakan tersebut dan tidak perlu membayar sewaannya (Majallah al-Ahkam al-Adliyyah n.d.).

\section{c. Idhä bațala al-sya'i bațala mā fĩ ḍamnih}

Arti dari kaidah di atas adalah "apabila sesuatu akad batal, maka batal pula yang ada dalam tanggungannya". Contohnya, penjual dan pembeli telah melaksanakan akad jual beli. Si pembeli telah menerima barang dan si penjual telah menerima uang. Kemudian kedua belah pihak membatalkan jual beli tadi. Maka, hak pembeli terhadap barang menjadi batal dan hak penjual terhadap harga barang menjadi batal. Artinya, si pembeli harus mengembalikan barangnya dan si penjual harus mengembalikan harga barangnya.

\section{d. Al-Jawāz al-syar' yunāfi al-ḍamān}

Arti dari kaidah di atas adalah "sesuatu yang dibolehkan oleh syara tidak dapat dijadikan objek tuntutan ganti rugi". Maksud kaidah ini adalah sesuatu yang dibolehkan oleh syariah baik melakukan atau meninggalkannya, tidak dapat dijadikan tuntutan ganti rugi. Contohnya, si A menggali sumur di tempat miliknya sendiri. Kemudian binatang tetangganya jatuh ke dalam sumur tersebut dan mati. Maka, tetangga tadi tidak bisa menuntut ganti rugi 
kepada si A, sebab menggali sumur di tempatnya sendiri dibolehkan oleh syariah.

\section{e. al-Mubāsyir ḍāmin wa in lam yata'ammad}

Arti dari kaidah di atas adalah "yang berbuat langsung bertanggung jawab meskipun tidak disengaja”. Contohnya seperti orang tergelincir kemudian orang lain tertimpa olehnya sehingga menyebabkan luka. Orang yang tergelincir itu harus bertanggung jawab karena kelalaian atau ketidak hati-hatiannya. Misal lain sopir menabrak seseorang karena ketidak hatihatiannya.

\section{f. al-Mutasabbib lā yaḍman illā bi al-ta'ammud}

Arti dari kaidah di atas adalah "pelaku tidak langsung tidak bertanggung jawab kecuali disertai kesengajaan". Contohnya: si A mengejar si B, kemudian si B menabrak si C. Si A tidak bertanggung jawab atas terlukanya si C, kecuali si A dengan sengaja mengarahkan si B ke si C, agar si C tertabrak (al-Jaziri 1990).

\section{g. Kullu mã șaḥha al-rahn bihi shaḥha ḍamānuhu}

Arti dari kaidah di atas adalah "setiap yang digadaikan, sah pula dijadikan jaminan"

\section{h. Ajruka 'alā qadri naṣbika (HR. Muslim)}

Arti dari kaidah di atas adalah "pahalamu adalah berdasarkan kadar usahamu". Maksud utama dari hadis di atas ialah untuk semua amal kebaikan, apabila ia semakin banyak diamalkan maka semakin bertambah pula fadhilahnya (Mudjib 2001). Apabila hadis tersebut diambil benang merahnya dengan kaidah al-ghunm bi al-ghurm dan al-kharāj bi al-ḍamān, maka akan muncul kaidah baru yang berbunyi, "hasil usaha sesuai dengan kadar biaya yang telah dikeluarkan dan keuntungan yang didapat berdasarkan kadar risiko yang dihadapi". Ini juga sesuai dengan kaidah al- 
Hendri Hermawan Adinugraha

ni'matu bi qadri al-nuqmati wa al-nuqmatu bi qadri al-ni'mati (Kenikmatan yang diraih berdasarkan kadar kesulitannya, dan kesulitan yang dihadapi berdasarkan kadar kenikmatan yang akan diraih) (Karim 2003).

\section{Konsep al-ghunm bi al-ghurm dalam Pembiayaan Mushārakah pada Perbankan Syariah}

Perkembangan ekonomi Islam identik dengan berkembangnya Lembaga Keuangan Syariah (LKS). Salah satu filosofi dasar ajaran Islam dalam kegiatan ekonomi dan bisnis, yaitu larangan untuk berbuat curang dan zalim. Semua transaksi yang dilakukan oleh seorang muslim haruslah berdasarkan prinsip rela sama rela ('an tarādin minkum), dan tidak boleh ada pihak yang menzalimi atau dizalimi. Prinsip dasar ini mempunyai implikasi yang sangat luas dalam bidang ekonomi dan bisnis, termasuk dalam praktik perbankan. Salah satu kritik Islam terhadap praktik perbankan konvensional adalah dilanggarnya prinsip "profit muncul bersama risiko" (al-ghunm bi alghurm). Dalam pembayaran bunga kredit dan pembayaran bunga deposito, tabungan dan giro, bank konvensional memberikan pinjaman dengan mensyaratkan pembayaran bunga yang besarnya tetap dan ditentukan terlebih dahulu di awal transaksi (fixed and predetermined rate). Sedangkan nasabah yang mendapatkan pinjaman tidak mendapatkan keuntungan yang fixed and predetermined juga, karena dalam bisnis selalu ada kemungkinan rugi, impas atau untung yang besarnya tidak dapat ditentukan dari awal (Karim 2003).

Diantara risiko (al-ghurm) dalam pembiayaan mushārakah ialah tidak terdapatnya suatu keabsolutan return sebagaimana sistem bunga, tetapi dilakukan sistem bagi hasil berdasarkan produktivitas riil dari dana dan usaha yang dikelola. Meskipun nisbah bagi hasil disepakati pada saat awal, tetapi pendapatan nyata dari bagi hasil ini baru diketahui setelah dana tersebut benar-benar menghasilkan profit. Hal yang bersifat absolut/mutlak dari sistem ini adalah nisbah bagi hasilnya, bukan profit-nya (nilai riil bagi 
hasilnya). Sehingga terdapat probabilitas fluktuasi dalam bagi hasil yang riil, tergantung pada produktivitas usahanya (Prabowo 2009).

Oleh karenanya, mengenakan tingkat bunga untuk suatu pinjaman merupakan tindakan yang memastikan sesuatu yang spekulatif (gharār), karena itu diharamkan. Bank konvensional menuntut mendapatkan untung yang fixed and predetermined tetapi menolak untuk menanggung risikonya (al-ghunm bilā ghurm). Bank konvensional mengharapkan hasil usaha, tetapi tidak bersedia menanggung biayanya (bilā al-kharāj). Padahal prinsipprinsip tersebut merupakan prinsip dasar dalam teori keuangan, yakni prinsip al-ghunm bi al-ghurm (Karim 2003).

Sebagai sebuah alternatif, Lembaga Keuangan Syariah termasuk perbankan syariah telah memformulasikan sistem interaksi kerja yang dapat menghindari aspek-aspek negatif dari sistem kerja bank konvensional, yaitu dengan menerapkan beberapa sistem, di mana harus diciptakan bank (lembaga keuangan) syariah yang tidak bekerja atas dasar bunga melainkan atas sistem bagi hasil, antara lain yang dikenal dalam fikih muamalah sebagai transaksi mushārakah dan muḍārabah (Karim 2003).

Secara etimologi, dalam kamus al-Munawwir, kata mushārakah dalam bahasa Arab berasal dari kata sharika (fíil māḍī), yashruku (fi'il muḍāri') sharikan/shirkatan/sharīkatan (mașdar/kata dasar); artinya menjadi sekutu atau syarikat. Menurut arti asli bahasa Arab, shirkah berarti mencampurkan dua bagian atau lebih sehingga tidak boleh dibedakan lagi satu bagian dengan bagian lainnya (Marwanto 2011). Kata sharika dalam Al-Qur'an, disebutkan sebanyak lebih kurang 170 kali, walau tak satu pun dari ayat ini yang menggunakan istilah mushärakah persis dengan arti kata kemitraaan dalam suatu kongsi bisnis (Saeed 2004). Istilah lain yang digunakan untuk mushārakah adalah sharikah atau shirkah mushārakah atau shirkah yang dari segi bahasa berarti percampuran (Muhammad, Teknik Perhitungan Bagi Hasil dan Profit Margin Pada Bank Syariah 2004). Dalam hal ini mencampur satu modal dengan modal yang lain sehingga tidak dapat dipisahkan satu sama lain.

Economica: Jurnal Ekonomi Islam - Volume 8, Nomor 1 (2017)

http://journal.walisongo.ac.id/index.php/economica 
Sedangkan secara terminologi, sharikah (perseroan) adalah transaksi antara dua orang atau lebih, yang dua-duanya sepakat untuk melakukan kerja yang bersifat finansial dengan tujuan mencari keuntungan (an-Nabhani 1996). Para fukaha mendefinisikannya sebagai akad antara orang-orang yang berserikat dalam hal modal dan keuntungan (Usman 2002). Sjahdeini mendefinisikan mushārakah sebagai kemitraan antara pihak bank dan pihak nasabah untuk bersama-sama memberikan modal dengan cara membeli saham untuk membiayai investasi (Sjahdeini 1999).

Secara teknis dalam aplikasi perbankan, mushārakah adalah kerja sama antara pemilik modal atau bank dengan pedagang/pengelola, di mana masing-masing pihak memberikan konstribusi modal dengan keuntungan dibagi menurut kesepakatan di muka dan apabila rugi ditanggung oleh kedua belah pihak yang bersepakat (Indonesia 2002). Melalui pembiayaan mushārakah yang disalurkan, bank syariah akan memperoleh profit berupa bagi hasil yang menjadi bagian bank syariah. Bersumber dari pengelolaan pembiayaan bagi hasil, bank syariah memperoleh pendapatan bagi hasil sesuai dengan nisbah yang telah disepakati dengan nasabah (Muhammad, Manajemen Pembiayaan Bank Syariah 2005). Karena pada dasarnya mushärakah adalah akad kerja sama diantara para pemilik modal yang mencampurkan modal mereka untuk tujuan mencari keuntungan (Muslim 2014).

Pada objek kerja transaksi mushārakah , partisipasi para mitra dalam pekerjaan merupakan dasar pelaksanaan musharakah. Akan tetapi, kesamaan porsi kerja bukanlah merupakan syarat. Seorang mitra boleh melaksanakan kerja lebih banyak dari yang lainnya, dan dalam hal ini ia boleh menuntut bagian keuntungan tambahan bagi dirinya. Setiap mitra melaksanakan kerja dalam musharakah atas nama pribadi dan wakil dari mitranya. Kedudukan masing-masing dalam organisasi kerja harus dijelaskan dalam kontrak (DSN 2013). 
Berdasarkan dari beberapa pengertian di atas, dapat disimpulkan bahwa mushārakah adalah suatu akad yang memuat sharing modal atau semaknanya dalam jumlah, jenis dan katakter tertentu dari seorang pemilik modal (șāhib al-mā $l$ ) kepada pengelola untuk dipergunakan sebagai sebuah usaha dengan ketentuan jika usaha tersebut mendatangkan hasil maka hasil (profit sharing) tersebut dibagi berdua berdasarkan kesepakatan sebelumnya, demikian juga sebaliknya (loss sharing). Karena profit atau laba serta kerugian dibagi serta ditanggungg bersama. Hal ini sejalan dengan maksud konsep kaidah al-ghunm bi al-ghurmi.

Secara yuridis normatif menurut Fatwa DSN MUI, jika mendapatkan keuntungan dalam transaksi mushārakah maka keuntungan harus dikuantifikasi dengan jelas untuk menghindarkan perbedaan dan sengketa pada waktu alokasi keuntungan atau penghentian musyarakah. Setiap keuntungan mitra harus dibagikan secara proporsional atas dasar seluruh keuntungan dan tidak ada jumlah yang ditentukan di awal yang ditetapkan bagi seorang mitra. Seorang mitra boleh mengusulkan bahwa jika keuntungan melebihi jumlah tertentu, kelebihan atau persentase itu diberikan kepadanya. Sistem pembagian keuntungan harus tertuang dengan jelas dalam akad. Kemudian apabila terjadi kerugian maka harus dibagi di antara para mitra secara proporsional menurut saham masing-masing dalam modal (MUI 2003).

Adapun nisbah keuntungan harus dibagi untuk kedua pihak. Salah satu pihak tidak diperkenankan mengambil seluruh keuntungan tanpa membagi kepada pihak yang lain. Selain itu proporsi keuntungan masing-masing pihak harus diketahui pada waktu persetujuan kontrak, dan proporsi tersebut harus dari keuntungan. Dalam kajian hukum muamalah, masalah akad atau perjanjian menempati posisi sentral, karena ia merupakan cara paling penting yang digunakan untuk memperoleh suatu maksud, terutama yang berkenaan dengan harta atau manfaat sesuatu secara sahih (al-Zarqā 1989). 
Dalam akad atau perjanjian terdapat pernyataan atas suatu keinginan positif dari salah satu pihak yang terlibat dan diterima oleh pihak lainnya, yang menimbulkan akibat hukum pada obyek perjanjian. Kesepakatan atau akad adalah salah satu bentuk perbuatan hukum (tașarruf) (Mas'adi 2002). Suatu tindakan dapat disebut sebagai akad atau perjanjian jika memenuhi beberapa rukun dan syarat. Rukun akad adalah unsur mutlak yang harus ada dan merupakan esensi dalam setiap akad. Jika salah satu rukun tidak ada secara syariah akad dipandang tidak pernah ada. Sedangkan syarat adalah suatu sifat yang mesti ada pada setiap rukun, tetapi bukan merupakan esensi akad. Seperti yang dimaksud dalam kaidah fikih al-Maqșūd fi al-uqūd mu'tabarah (al-Sa'îdān t.th). Sehingga, dalam menjalin beberapa ketentuan transaksi antara LKS dan nasabah, sistem mushārakah telah mengatur beberapa hal yang berkaitan dengan mekanisme kesepakatan (akad) pembiayaan mushārakah dan mekanisme pelaksanaan profit and loss sharing sesuai dengan kebijakan LKS-nya masing-masing.

Pada dasarnya, implementasi konsep kaidah al-ghunm bi al-ghurm dalam pembiayaan mushārakah tidak jauh berbeda dengan pembiayaan muḍārabah pada perbankan syariah. Mengingat menurut Fatwa DSN MUI (2003) bahwa, muḍārabah yaitu akad kerjasama suatu usaha antara dua belah pihak di mana pihak pertama (mālik, șāḥib al-māl, LKS) menyediakan seluruh modal, sedang pihak kedua ('âmil, muḍārib, nasabah) bertindak selaku pengelola, dan keuntungan usaha bagi di antara mereka sesuai kesepakatan yang dituangkan dalam kontrak (MUI 2003).

Letak perbedaan mendasar antara muḍārabah dengan mushārakah ialah bahwa pada akad muḍ̄abahah lebih menekankan kerjasama mitra usaha dan investasi dan kerjasama dengan kontribusi 100\% modal dari șāhib al-māl dan keahlian atau skill dari muḍārib. Sedangkan pada akad mushārakah lebih mengedepankan kerjasama modal usaha antara dua pihak atau lebih untuk suatu usaha tertentu, tentunya baik pada akad muḍārabah 
maupun pada akad mushārakah memperhatikan kontribusi dana dengan keuntungan dan risiko akan ditanggung bersama sesuai dengan kesepakatan yang dituangkan dalam kontrak.

Hanya saja pada praktiknya, pembiayaan mudārabah dan mushārakah pada perbankan syariah sering diaplikasikan atau diterapkan pada produk simpanan atau tabungan (funding), sebab lebih simpel dan sederhana jika ditinjau dari segi pengelolaan dan operasionalnya. Jika akad mushārakah diaplikasikan dalam pembiayaan, dapat dipastikan mushārakah sangat jarang ditemukan dikarenakan tingkat ghurmu-nya yang sangat tinggi. Tingginya risiko (al-ghurm) yang dihadapi oleh bank syariah (șāhib al-māl) dalam mengimplementasikan akad muḍārabah dan mushārakah pada pembiayaan produktif menyebabkan pihak bank menerapkan standar analisis yang lebih ketat dibandingkan dengan akad murābaḥah. Bank syariah juga mengalami kesulitan dalam menjalankan adverse selection, untuk mengetahui karakter nasabah yang sebenarnya dan kelayakan atau kemampuan nasabah yang sebenarnya dalam menjalankan/mengorganisir usahanya (Ardiansyah 2013).

Padahal jika usahanya meraih sukses maka secara otomatis tingkat ghunmu-nya juga tinggi. Maka, seharusnya pembiayaan muḍarabah dan mushārakah bisa menjadi produk unggulan dan seyogyanya dapat menjadi produk yang paling dominan pada perbankan syariah sebagai bank yang selalu menjunjung tinggi jargon "bagi-hasil" dengan branding "syariah" dan kerap diidentikkan dengan agama Islam itu sendiri, dan bank yang seringkali memprioritaskan prinsip keadilan ('adl) dan pelarangan darār bagi semua pihak dalam bermuamalah. Sebagaimana termaktub dalam kaidah fikih al-așl huwa al-'adl fì kulli al-mu'āmalāt wa murā'āt al-țarafaini wa raf'u al-ḍarari 'anhumā (al-Sa'īdān t.th). 


\section{Al-Ghurm pada Pembiayaan Mushārakah}

Pada produk pembiayaan, terdapat banyak akad yang diterapkan berdasarkan syariat Islam, salah satunya akad mushārakah (Rauf 2012). Akad mushārakah ini menjalankan prinsip bagi hasil di mana antara bank dan nasabah sama-sama menanamkan modalnya untuk menjalankan suatu kegiatan usaha dan keuntungan dari hasil usaha bersama ini dibagikan baik menurut proporsi penyertaan modal masing-masing maupun sesuai dengan kesepakatan bersama (unproportional). Jika terjadi kerugian, maka pertanggung jawaban kerugian ditanggung oleh para pihak selaku pemilik modal sesuai dengan batas modal masing-masing.

Selanjutnya oleh karena konsep kaidah al-ghunm bi al-ghurm ini, pembiayaan mushārakah pada perbankan syariah rentan akan risiko-risiko, bahkan faktor inilah yang menyebabkan tidak banyaknya perbankan syariah yang belum/bahkan tidak berminat untuk mengaplikasikan pembiayaan mushārakah . Pembiayaan mushārakah memiliki beberapa risiko (al-ghurm) yang harus dikendalikan dengan manajemen risiko yang handal dan mumpuni, risiko pembiayaan mushārakah dibagi menjadi 3 (tiga) jenis yaitu (Karim 2003) :

\section{a. Risiko Bisnis (Business Risk)}

Yaitu risiko yang ditimbulkan dari aktifitas bisnis itu sendiri. jika untung, pembagian berdasarkan nisbah, sedagkan kalau rugi pembagian berdasarkan proporsi modal. Jika bisnis rugi, maka sesungguhnya pengelola usaha akan menanggung kerugian. Bila yang dikontribusikan adalah uang, maka risikonya adalah hilangnya uang tersebut, sedangkan bila yang dikontribusikan adalah kerja, maka risiko adalah hilangnya kerja, usaha dan waktunya dengan tidak mendapatkan hasil apapun atas jerih payahnya dalam bisnis. 
b. Risiko Karakter (Character Risk)

Bila kerugian terjadi karena kesalahan pengelola usaha, misalnya karena dia lalai dan/atau melanggar persyaratan-persyaratan kontrak mushārakah , maka șāhib al-māl tidak perlu menanggung kerugian.

c. Risiko Pembiayaan (Credit Risk)

Yaitu risiko yang timbul sebagai akibat keteledoran/kecerobahan pihak șāhib al-māl dalam melaksanakan tugasnya, risiko ini dapat bersumber dari berbagai aktifitas fungsional bank syariah seperti penyaluran dana (pembiayaan) dan penghimpunan dana (funding), bisa juga risiko ini timbul karena kinerja buruk pihak pengelola usaha (Arifin 2003).

Risiko (al-ghurm) yang terdapat dalam mushārakah, terutama dalam penerapannya dalam pembiayaan relatif tinggi. Di antaranya:

1) Karakter nasabah yang kurang baik atau tidak amanah (tidak jujur).

2) Pelaporan keuangan tidak sesuai dengan kenyataan (manipulasi dalam statmen keuangan).

3) Side streaming atau nasabah tidak menggunakan dana sebagaimana kesepakatan dalam akad.

4) Kecerobohan dan kesalahan yang disengaja oleh nasabah.

5) Nasabah tidak mampu menjaga stabilitas usaha serta tidak mampu mengelola kondisi keuangan sesuai dengan prinsip kehati-hatian (prudential).

6) Tidak ada pencatatan dan pembukuan yang jelas (khususnya pada UMKM).

7) Banyak anggapan masyarakat bahwa pembiayaan mushārakah sebaiknya tanpa jaminan (anggunan), padahal ini termasuk bisnis beresiko tinggi sesuia dengan prinsip prudential banking. Karena risiko 
No. 1 (tidak sedikit karakter nasabah yang kurang baik atau tidak amanah (tidak jujur).

Macam-macam risiko pembiayaan mushārakah di atas, bukan untuk dihindari melainkan harus dihadapi dan dikendalikan secara efektif, karena risiko yang dihadapi oleh bank syariah dapat menyebabkan kegagalan yang fatal apabila tidak dikelola dengan baik. Akan tetapi jika sebaliknya maka bank syariah akan mendapatkan al-ghunm sebagai imbal hasilnya. Pada dasarnya, semua pembiayaan yang ada dalam perbankan memiliki tingkat risiko yang bervariasi sesuai dengan jumlah nominal, waktu, tempat dan kondisi. Untuk mengantisipasi hal tersebut, maka penting bagi bank syariah untuk melakukan pengendalian risiko (al-ghurm) sehingga trust kian bertambah dan seyogyanya akan berpengaruh terhadap peningkatan pendapatan bank syariah (Khuriawati 2011). Usaha untuk meminimalkan alghurm pada pembiayaan mushārakah dapat digunakan alat-alat analisa calon nasabah yang biasa digunakan dalam perbankan konvensional maupun syariah, yaitu menggunakan prinsip-prinsip seperti 5C. Berikut ini penjelasannya (Antonio 2001):

Pertama, capital (modal/kekayaan). Modal adalah salah satu yang menjadi penilaian oleh pihak bank syariah (șạhib al-māl) dalam menganalisis sebuah pembiayaan mushārakah, modal merupakan kebutuhan utama dalam mendirikan sebuah usaha atau sebagai sumber pembiayaan pertama.

Kedua, collateral (barang jaminan/anggunan). Barang jaminan merupakan hal yang penting dalam pelaksaan pembiayaan termasuk mushārakah karena dengan adanya jaminan selain menjaga keamanan atas pembiayaan yang akan memotivasi nasabah untuk tetap rajin dan tidak lalai atas kewajibannya dalam melunasi pembiayaan yang dilakukan.

Ketiga, capacity (kemampuan utnuk membayar hutang). Kemampuan nasabah dalam mengelola dan menjalankan usaha serta modal kerja yang ia miliki tentunya sangat perlu dalam menjalankan usaha yang ia lakukan 
tersebut pastinya memerlukan modal dan juga dana pihak ketiga termasuk bank syariah, jika nasabah tidak mampu mengelola usahanya maka disinilah bank syariah harus melihat seberapa besar kemampuan nasabah dalam mengembalikan pembiayaan yang ia lakukan baik dari segi kredit maupun jaminan.

Keempat, condition (kondisi/lingkungan). Penilaian yang dilakukan disini berkenaan dengan bagaimana prospek kegiatan usaha yang dimiliki oleh si pemohon pembiayaan atau nasabah apakah memiliki risiko tinggi atau tidak, dan apakah usaha yang dilakukan tersebut mengganggu lingkungan sekitarnya atau sebaliknya.

Kelima, character (watak/sifat). Berbicara tentang karakter atau sifat di sini pihak bank syariah pastinya tidak akan mau mengambil risiko, maka dalam hal ini bank syariah akan melakukan penelitian atau penjajakan atas pemohon atau nasabah, apakah nasabah memiliki perilaku, etika, dan akhlak yang baik atau tidak, serta apakah nasbah menjalin hubungan yang baik dengan masyarakat sekitarnya termasuk keluarga.

Prinsip lain yang harus dilakukan oleh pihak bank syariah dalam melakukan pembiayan mushārakah terhadap nasabah antara lain 3R, yaitu: (Muhammad, Manajemen Pembiayaan Bank Syariah 2005).

Pertama, return principle. Pihak bank syariah harus menilai tentang pemberian pembiayaan yang dilakukannya akan menghasilkan profit/laba dan juga kemampuan nasabah dalam mengembalikan dana atas pembiayaan tersebut. Kedua, payment capacity. Hal ini berkaitan dengan kemampuan nasabah dalam mengembalikan pinjaman dana pembiayaan kepada bank syariah dengan tepat waktu. Ketiga, risk breaking. Bank syariah juga harus dapat mengetahui tingkat kemungkinan risiko yang akan dihadapinya jika melakukan atau merealisasikan suatu pembiayaan tertentu.

Tidak semua alat analisis atau prinsip-prinsip di atas dapat diterapkan semuanya, namun setidaknya banyak hal yang menjadi perhatian dan 
pertimbangan bank syariah sebelum memutuskan suatu pembiayaan. Selain prinsip-prinsip di atas tadi untuk mengetahui seberapa dalam penelitian atau analisis data tersebut ditentukan pula melalui hal-hal sebagai berikut (Sutojo 1997) :

1. Jumlah dana pembiayaan yang akan diberikan. Semakin besar jumlah dana yang akan diberikan, semakin besar pula risikonya. Karena itulah, makin besar pembiayaan yang diminta makin tinggi pula kehati-hatian dalam menganalisis data yang ada.

2. Jangka waktu pembiayaan. Semakin lama jangka waktunya, maka tingkat resiko pembiayaan tersebut akan lebih tingi pula, dan semakin tinggi risiko bank syariah akan makin berhati-hati dalam penyaluran dana tersebut.

3. Jaminan yang disediakan. Jika nilai jaminan yang disediakan untuk calon nasabah lebih tinggi dari pada bearnya pembiayaan yang diajukan, maka pihak bank syariah akan lebih mudah dalam melakukan analisa.

4. Reputasi debitur atau pengelola usaha. Makin baik reputasi calon nasabah, maka bank syariah akan lebih mudah dalam memberikan permohonan pembiayaan.

5. Relationship yang baik. Hubungan ini dapat berupa pembukuan tabungan, gaji atau pernah menjadi nasabah dalam suatu pembiayaan. Jika bank syariah telah atau pernah mengenal calon nasabahnya, biasanya ini akan lebih mempermudah proses analisa kelayakan usaha yang diajukan.

\section{Simpulan}

Perbankan syariah memiliki posisi unik dibandingkan dengan bank konvensional, yaitu diperbolehkannya bank syariah melakukan aktivitas usaha yang bersifat multifinance dan perdagangan (trading) melalui akad jual beli. Tetapi sayangnya, keunikan tersebut dominan diaplikasikan dalam 
penghimpunan dana perbankan syariah. Padahal ada hal lain yang lebih urgent, yaitu khitthah perbankan syariah sebagai bank bagi hasil, bukan hanya dalam penghimpunan dana akan tetapi juga pembiayaan, yang justru banyak diakses serta dibutuhkan oleh kalangan masyarakat menengah ke bawah.

Salah satu pembiayaan yang masyhur bersifat bagi hasil serta bagi rugi pada perbankan syariah yaitu pembiayaan mushārakah. Di mana mushārakah dalam literatur fikih berbentuk perjanjian kepercayaan ('uqud al-amānah) yang menuntut tingkat kejujuran yang tinggi dan menjujung rasa keadilan. Karenanya masing-masing pihak harus menjaga kejujuran untuk kepentingan bersama, dan setiap usaha dari masing-masing pihak untuk tidak melakukan kecurangan dan ketidakadilan pembagian pendapatan, sebab akan merusak ajaran Islam dan menimbulkan image yang negatif.

Oleh karena pembiayaan mushārakah itu basisnya 'uqūd al-amānah, maka semua pihak yang terkait harus benar-banar mempunyai sifat amānah (trust) dan bertanggung jawab. Tidak heran jika dua pembiayaan ini sangat sulit diterapkan, melihat ghurm-nya juga sangat tinggi dan rentan akan wanprestasi. Padahal jika ini diaplikasikan dalam perbankan syariah ghunmnya juga akan lebih besar dan akan menjadikan pembeda yang signifikan dengan perbankan konvensional, dibandingkan dengan pembeda-pembeda lainnya yang dikira sudah biasa.

Pepatah ekonom dahulu mengatakan "modal sedikit untung sebesarbesarnya". Statemen ini agaknya sudah kurang relevan lagi dengan konteks dewasa ini. Karena proporsi besar dan kecilnya modal juga menentukan porsi ghunm dan ghurm yang akan diraih serta dihadapi. Islam memiliki solusi yang lebih arif dan sangat relevan melalui kaidah fikih yang berbunyi: al-ghunm bi al-ghurm (untung muncul bersama risiko). Akan lebih baik lagi apabila kaidah ini diimplementasikan pada pembiayaan mushārakah di perbankan syariah.

Economica: Jurnal Ekonomi Islam - Volume 8, Nomor 1 (2017) http://journal.walisongo.ac.id/index.php/economica 


\section{Daftar Pustaka}

al-Jaziri, Abdurrahman. 1990. al-Fiqh 'alā al-Madhāhib al-'Arba'ah. Beirut: Dār al-Fikr.

al-Kamil, Umar Abdullah. t.t. al-Qawā'id al-Fiqhiyyah al-Kubrā wa Āthāruhā fi al-Mu'āmalāt al-Māliyyah. Mesir: Jāmi'ah al-Azhar al-Syarîf.

al-Sa'īdān, Walīd bin Rāshid. t.th. Qawā'id al-Buyu'wa Farāid al-Furū'. t.t: t.p.

al-Zarqā, Mușțafā Ahmad. 1989. al-Fiqh fi Thaubihi al-Jadīd. Beirut: Dār alFikr.

an-Nabhani, Taqiyuddin. 1996. Membangun Sistem Ekonomi Alternatif Perspektif Islam. Surabaya: Risalah Gusti.

Antonio, Muhammad Syafii. 2001. Bank Syariah: Dari Teori ke Praktik. Jakarta: Gema Insani Press.

Ardiansyah, Dimas. 2013. "Implementasi Pembiayaan dengan Akad Mudharabah (Studi pada 3 Bank Syariah di Kota Malang)." Dimas Ardiansyah, "Implementasi Pembiayaan dengan Akad Mudharabah (Studi pada 3 Bank SyaJurnal Ilmiah Mahasiswa FEB 1 (2): 15.

Arifin, Zainal. 2003. Dasar-Dasar Manajemen Bank Syari'ah. Jakarta: Alvabet.

Djazuli, A. 2006. Kaidah-Kaidah Fikih: Kaidah-Kaidah Hukum Islam dalam Masalah-Masalah yang Praktis. Jakarta: Kencana.

DSN. 2013. "Pembiayaan Musyarakah." http://www.dsnmui.orid/ index.php?mact=News,cntnt01, detail,0\&cntnt01articleid= 11\&cntnt01returnid=59. diakses February 21, 2017.

Indonesia, Tim Penggembangan Perbankan Syariah Institut Bankir. 2002. Konsep, Produk, dan Implementasi Operasional Bank Syariah. Jakarta: Djambatan.

Karim, Adiwarman A. 2003. Bank Islam: Analisis Fiqh dan Keuangan. Jakarta: IIIT Indonesia.

Khuriawati. 2011. "Pengaruh Manajemen Risiko dan Emotional Spiritual Quotient (ESQ) Terhadap Kinerja Pembiayaan Mudharabah Tanpa Jaminan (Survei BMT di Kabupaten Purworejo). Skripsi, Semarang: Fakultas Syari'ah Institut Agama Islam Negeri Walisongo.

t.thn. "Majallah al-Ahkam al-Adliyyah.” Pasal 416. 
Marwanto, Eko. 2011. http://www.ekomarwanto.com/2011/11/ musyarakah-mudharabah-muzaraah.html. Diakses February 21, 2017.

Mas'adi, Ghufran A. 2002. Fiqih Muamalah Kontekstual. Jakarta: Raja Grafindo Persada.

Mudjib, Abdul. 2001. Kaidah-Kaidah Ilmu Fiqh (al-Qowa'idul Fiqhiyyah). Jakarta: Kalam Mulia.

Muhammad. 2001. Bank Syari'ah: Analisis Kekuatan, Peluang, Kelemahan dan Ancaman. Yogyakarta: Ekonomia.

Muhammad. 2005. Manajemen Pembiayaan Bank Syariah. Yogyakarta: UPP AMP YKPN.

Muhammad. 2004. Teknik Perhitungan Bagi Hasil dan Profit Margin Pada Bank Syariah. Yogyakarta: UII Press.

MUI, Tim Penulis Dewan Syari'ah Nasional. 2003. Himpunan Fatwa Dewan Syari'ah Nasional. Jakarta: PT. Intermasa.

Muslim, Muhammad Arfan, Julimursyida. 2014. "Pengaruh Pembiayaan Murabahah Dan Musyarakah Terhadap Profitabilitas (Studi pada BPR Syariah di Indonesia)." Jurnal Magister Akuntansi Pascasarjana Universitas Syiah Kuala 87.

Prabowo, Yudho. 2009. "Analisis Risiko dan Pengembalian Hasil pada Perbankan Syariah: Aplikasi Metode VaR dan RAROC pada Bank Syariah Mandiri." Jurnal La_Riba III (1): 94.

Rauf, Abdul. 2012. "Penerapan Teori Akad Pada Perbankan Syariah." AlIqtishad: Jurnal Ilmu Ekonomi Syariah (Abdul Rauf, "Penerapan Teori Akad Pada Perbankan Syaria Fakultas Syariah dan Hukum, UIN Syarif Hidayatullah) IV (1): 17.

Rejeki, Fanny Yunita Sri. 2013. "Akad Pembiayaan Murabahah dan Praktiknya Pada PT. Bank Syariah Mandiri Cabang Manado." Jurnal Lex Privatum I (2): 25.

Saeed, Abdullah. 2004. Menyoal Bank Syariah: Kritik Atas Interpretasi Bunga Bank Kaum NeoRevivalis. Jakarta: Paramadina.

Sjahdeini, Sutan Remy. 1999. Perbankan Syariah. Jakarta: Pustaka Utama Grafiti.

Economica: Jurnal Ekonomi Islam - Volume 8, Nomor 1 (2017)

http://journal.walisongo.ac.id/index.php/economica 
Hendri Hermawan Adinugraha

Sutojo, Siswanto. 1997. Menangani Kredit Bermasalah: Konsep, Teknik dan Kasus (Seri Manajemen Bank No. 4). Jakarta: Pustaka Binaman Pressindo.

Ubaid, Abu. t.t. Kitāb al-Amwāl. Beirut: Dār al-Fikr.

Usman, Rachman. 2002. Aspek-Aspek Hukum Perbankan Islam di Indonesia. Bandung: PT. Citra Aditya Bakti. 